\title{
O Círculo Vicioso da Violência Sexual: Do Ofendido ao Ofensor
}

The vicious circle of the sexual violence:

From the offended to the offender

Núbia Angélica de Jesus Universidade Católica de Goiás

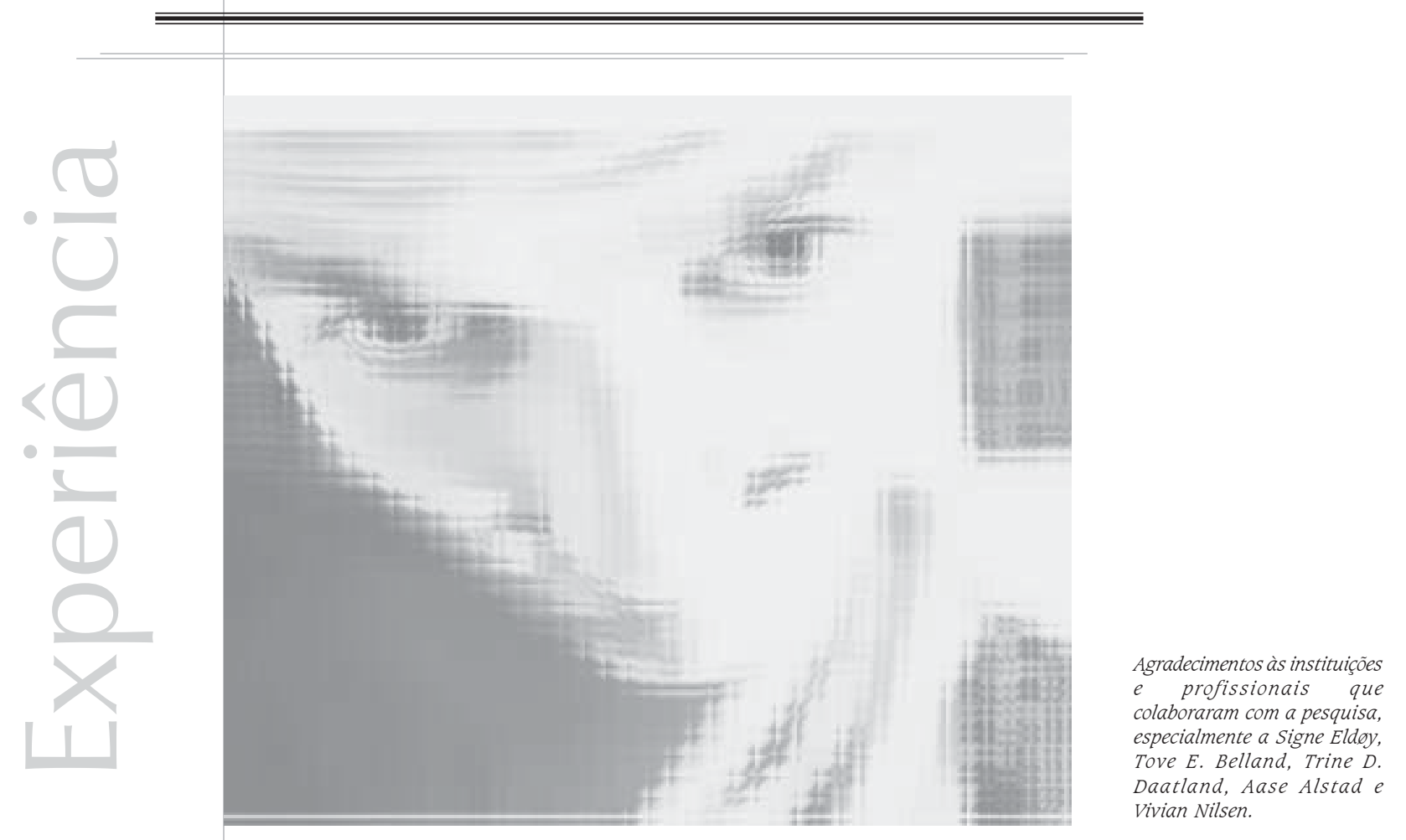


Resumo: O presente trabalho discute o fenômeno da violência sexual contra crianças e adolescentes pondo em foco o autor do ato. Objetivou-se compreender o processo de formação da violência empregada, tendo em vista a experiência de violência anteriormente sofrida pelo autor, com base em uma visão fenomenológico-existencial. Para ilustração, foram inseridos trechos de atendimentos psicoterápicos realizados com um autor de violência sexual, de trinta e um anos, preso há onze anos em regime fechado. Foram realizadas vinte e nove sessões, que fizeram parte do Projeto Invertendo a Rota, vinculado ao CEPAJ/UCG. Concluiu-se, por meio dos atendimentos, que a imagem do abuso sexual sofrido na infância influenciou a forma como o sujeito cometeu a violência na idade adulta. Com o trabalho psicoterápico, percebeu-se ainda que o sujeito pôde ampliar percepções construídas acerca de si mesmo e do outro, começando, assim, um processo de ressignificação de sua própria história.

Palavras-chave: autor de violência sexual, repetição, prisão, psicoterapia.

Abstract: The present essay brought the issue of the sexual violence against children and adolescents, with emphasis on the author of the law breaking act. The objective was to comprehend the process of violence formation, taking into account the previous experience of the violence suffered by the author. It was used as reference a phenomenological-existential view. To illustrate, passages of psychological appointments with a male, thirty one years old, author of sexual violence, arrested for eleven years in closed regime were inserted. Twenty nine sessions were made as part of the project "Invertendo a Rota", linked to CEPAJ/UCG. It was concluded, with the appointments, that the image of the sexual abuse suffered in childhood influenced the way the person practiced the violence in adult age. After psychotherapy, it was noticed that the subject was able to enlarge the perceptions he had about himself and others, starting a resignification of his own life.

Key words: sexual violence author, repetition, prison, psychotherapy.

\section{Psicoterapia de base fenomenológico-existencial}

Uma abordagem terapêutica com base na fenomenologia busca proporcionar ao paciente uma ampliação da consciência. Nesse sentido, trabalha-se, por meio do diálogo, com aquilo que se mostra por si mesmo, buscando o sentido da pessoa. Isso significa ir à coisa mesma, de forma que se consiga um maior contato consigo mesmo e com o outro. Essa ampliação, por sua vez, não pode ser imposta ao sujeito, mas deve desenvolver-se internamente, pois é ela que lhe permitirá trabalhar situações inacabadas, reorganizá-las e compreender de que forma continua repetindo-as no presente.

Por meio da visão de saúde-doença fenomenológica, buscou-se, neste estudo, abordar a temática do abuso sexual contra crianças e adolescentes, com foco no autor da violência. Tendo em vista o grande número de pesquisas realizadas sobre pessoas que sofreram violência sexual (Gabel, 1997; Azevedo; Guerra, 1988, 1989, 1995; Bass; Thorton, 1985; Sousa; Morais, 1997; Furniss, 1993; etc) e a defasagem de estudos sobre o autor de crimes sexuais, faz-se necessário conhecer mais sobre as motivações e dramas dessas pessoas, não com o intuito de rotulálas, enquadrando-as em um tipo específico de transtorno, mas com o objetivo de apreender a realidade existencial do sujeito em questão bem como o processo de formação da violência empregada.

Isso está em consenso com a maneira na qual a fenomenologia enxerga o ser humano,
"Olho por olho... e o mundo acabará cego".

Gandhi 
tentando compreendê-lo como se mostra a partir do movimento de epochè. Hycner (1995) e Augras (1986/2002) afirmam que a epochè envolve a suspensão do diagnóstico de doença dado ao paciente, para que se possa vê-lo além de um estigma, ou patologia, visto que o diagnóstico em categorias pode ocultar a realidade existencial da pessoa. Assim, a patologia em uma abordagem fenomênico-existencial é entendida a partir da história de vida interna de uma singularidade, que, por não ser comparável e muito menos restringida a uma certa categorização, ultrapassa o conceito clássico de normalidade (Petrelli, 1999).

Portanto, para encontrar verdadeiramente a pessoa que busca a psicoterapia, é necessário olhá-la além de nossos pré-conceitos. O sujeito que se apresenta perante o terapeuta é mais do que um ladrão, homicida ou estuprador; trata-se de uma pessoa, portanto, deve ser vista em sua totalidade, e não de forma fragmentada. Dessa forma, faz-se necessária uma análise individual, cultural e social dos autores de crimes sexuais.

A psicoterapia de base fenomenológicoexistencial considera que o cliente seja o único que pode decidir sobre si próprio, sendo responsável por suas escolhas (Augras, 19862002). A psicoterapia visa, então, identificar o "problema" como pertencente ao sujeito, no intuito de reintegrá-lo, e não de excluí-lo, para que se possa captar os significados mais profundos do indivíduo e, assim, abrir espaço para um diálogo com o outro. Isso acarreta a conseqüente promoção da noção de responsabilidades no sujeito (Hycner, 1995).

\section{O circulo vicioso da violência sexual}

Cohen e Figaro (1996) ressaltam que a relação sexual é um tipo particular de relação social e possui limites individuais e sociais. Freud (1905, citado por Cohen; Figaro, 1996) entende que a sexualidade madura implica a escolha de outra pessoa como objeto sexual. Entretanto, no caso da perversão, a escolha recai sobre uma pessoa tratada como objeto parcial, ou mesmo sobre um objeto inanimado (ex. fetichismo), ou ainda sobre outras pessoas, sempre não respeitando sua autonomia.

Dessa forma, entende-se por abuso sexual qualquer relacionamento interpessoal no qual o ato sexual seja veiculado sem o consentimento da outra pessoa, ocorrendo com ou sem violência, seja esta física e/ou psicológica (Cohen; Figaro, 1996).

Koshima (2003) destaca que, em geral, se aceita que o abuso contra uma criança seja uma violência, mesmo quando não há marcas físicas evidentes, visto que presume a fragilidade física e emocional da criança para defender-se. Entretanto, em relação aos adolescentes, é comum que estes sejam acusados de provocar, induzir e consentir com a violência sexual sofrida. Contudo, a validade de um consentimento é algo subjetivo, e usar esse termo só faz sentido quando os envolvidos têm recursos simbólicos suficientemente desenvolvidos, o que não acontece entre um adulto e um adolescente. De acordo com Miller (1997), toda criança procura contato amoroso, e é feliz ao recebêlo. Entretanto, ficará insegura se lhe forem despertadas sensações que não ocorreriam espontaneamente nesse estágio de seu desenvolvimento. Quando a criança é vista como uma propriedade com a qual o adulto tenta atingir algum objetivo ou exercer poder sobre ela, seu crescimento vital estará violentamente comprometido.

Em uma pesquisa realizada por Rada (1978, citado por Cohen; Figaro, 1996) sobre pessoas que cometeram ato sexual ilícito, foi concluído que, mais do que uma violência social, esse tipo de crime envolve também poder, controle e humilhação. Há sempre, no abuso sexual 
contra crianças e adolescentes, uma relação estabelecida de poder que é desigual, na qual caberia ao adulto impor o limite e dizer não. Jacobson (1975, citado por Balier, 1997) afirma que, no desenvolvimento de pacientes que cometem ato sexual, existiram dificuldades de identificação com um modelo adulto de comportamento sexual, fator responsável pela criação de uma patologia do superego.

Com base nisso, Balier (1997) destaca que o encarceramento, por si só, de nada serve, contudo, este é necessário, visto que, se faltou a interiorização do superego, é essencial existir um quadro externo que o represente.

Em relação ao encarceramento, Tavares e Menandro (2004) lembram que as prisões, no Brasil, funcionam como meios de se oficializar a exclusão que já paira sobre os detentos, como um atestado de exclusão com firma reconhecida. Fazem tal afirmação levando em consideração não só o estado de precariedade das prisões como também o estado de precariedade em que se encontram as pessoas antes do encarceramento, que, em grande parte das vezes, são provenientes de grupos já marcados pela exclusão social. Dessa forma, as prisões podem até mudar alguma coisa nos indivíduos que nelas vivem, mas não alteram a perspectiva com a qual os indivíduos convivem: a de que as condições sociais de seu passado estarão presentes também em seu futuro, ou seja, para o detento brasileiro, não há prognóstico, somente o diagnóstico de bandido.

Neste sentido, Esber (2005) afirma que medidas estritamente punitivas são insuficientes para coibir reincidências. Grande parte dos indivíduos que cometeram agressão sexual, se não acompanhados por um tratamento terapêutico, cumprirão sua pena, sairão da prisão e continuarão a realizar as mesmas práticas, o que gera uma situação repetitiva.

De acordo com Furniss (1993), existem vários fatores predisponentes que podem contribuir para que uma pessoa cometa abuso sexual. Afirma que muitos abusadores sofreram abusos físicos e outros desenvolveram perturbações de personalidade em decorrência de um severo abuso e privação emocional.

Algumas pesquisas dizem que certos abusadores sexuais foram vítimas de abuso sexual quando crianças, e que, a cada oito crianças abusadas, uma repetirá o comportamento na idade adulta. Segundo Ray Wyre (1996, citado por Sanderson, 2005, p. 55), "para entender porque algumas vítimas passam a praticar abusos, é preciso prestar atenção ao tipo de abusador, à relação formada com a criança e à experiência da criança com o abuso".

Miller (1997) revela que muitas pessoas repetem, com outras, as atrocidades que receberam, pois não conseguem vivenciar, de forma consciente, os males que lhes foram imputados na infância. Não querem olhar para sua história, e, dessa forma, não sabem que, no fundo, são continuamente determinadas pela mesma, já que vivem situações nãoresolvidas e reprimidas na infância, o que produz um círculo vicioso.

Segundo a autora, o medo da criança, que é fraca e indefesa, dá ao adulto a sensação de força, de permitir que manipule o medo no outro, algo que não pode fazer consigo mesmo. Acrescenta que, dessa forma, o desprezo pelo mais fraco se torna uma defesa contra o irrompimento dos próprios sentimentos de impotência. Explicita, ainda, que o forte é aquele que sabe de sua impotência porque a vivenciou, e, portanto, não tem necessidade de mostrar sua força por meio do desprezo.

Assim, a partir do momento em que a pessoa puder vivenciar de que forma fora manipulada e lesada quando criança e quais desejos de vingança foram despertados, poderá perceber, mais claramente, as manipulações, e terá menos necessidade de manipular os outros. Nesse sentido, pessoas que descobriram seu
Miller (1997) revela que muitas pessoas repetem, com outras, as atrocidades que receberam, pois não conseguem vivenciar, de forma consciente, os males que Ihes foram imputados na infância. 
passado e aprenderam a esclarecer seus sentimentos e a pesquisar seus verdadeiros motivos não estão mais pressionadas a transferir seu ódio aos inocentes. Elas podem odiar o odiável e amar o amável, sem cair na cegueira da criança maltratada que procura 'bodes expiatórios' para poupar quem verdadeiramente merece seu ódio (Miller, 1997).

Por meio do relacionamento terapêutico, o indivíduo pode reconstruir pensamentos, sentimentos e impressões a respeito da violência cometida. A violência portanto, deve ser considerada um fenômeno relacional, e não individual, segundo Esber (2005, p. 75):

"Para uma instância abusadora, existe uma instância abusada e uma instância contextual reforçadora do abuso. Desta última, participamos todos, que reforçamos a manutenção da violência sexual com nossos mitos e tabus - mesmo que de forma inconsciente".

É, portanto, dentro do conceito fenomenológico de que a pessoa deve ser compreendida em sua totalidade, o que vai além do estigma e da "patologia", que se baseia o trabalho aqui proposto. Olhar fenomenologicamente para uma pessoa que tenha cometido agressão sexual é também olhar para a vítima, para o social, o cultural e, sobretudo, para nós mesmos.

\section{Método}

\section{Participante}

Este estudo foi realizado com um sujeito que cumpre pena em regime fechado na Agência Goiana do Sistema Prisional, respondendo pelo art. 214 do Código Penal Brasileiro - Atentado Violento ao Pudor. O sujeito Henrique (nome fictício) de trinta e um anos de idade, mecânico, estudou até a sexta série do primeiro grau e cumpre pena há onze anos por ter abusado sexualmente de dois adolescentes (um com treze e outro com quatorze anos).

\section{Material}

Foi utilizado um consultório de Psicologia da Agência Goiana do Sistema Prisional, mobiliado com uma mesa e duas cadeiras. Para o registro das sessões, fez-se uso de um minigravador e fitas K-7.

\section{Procedimento}

Inicialmente, fora realizada uma consulta aos arquivos do presídio, com o objetivo de selecionar as fichas de autores de abusos sexuais contra crianças ou adolescentes. Após essa seleção, foi feita a proposta do atendimento a Henrique por meio de uma assistente social do presídio. O atendimento fez parte de ações do Programa Repropondo - Programa de Atendimento a Autores de Violência Sexual - do Projeto Invertendo a Rota, vinculado à Universidade Católica de Goiás pelo Centro de Estudos, Pesquisa e Extensão Aldeia Juvenil (CEPAJ).

Os atendimentos iniciaram-se no final de maio de 2005, sendo finalizados em fevereiro de 2006. Foram realizadas vinte e nove sessões, com encontros semanais de aproximadamente uma hora cada.

\section{Resultados e discussão}

No decorrer dos atendimentos, ao falar sua história familiar Henrique conta que nunca chegou a morar com o pai, pois o mesmo tinha outra família quando ele nasceu. $\mathrm{O}$ vínculo maior que possuía era com a mãe. Contudo, esta faleceu quando Henrique tinha cinco anos de idade. Depois disso, com nove anos de idade, passou a morar em fazendas e a trabalhar para outras pessoas.

Aos dez anos, Henrique foi abusado sexualmente em uma dessas fazendas por seu patrão, João (nome fictício). Essa informação não constava no processo judicial, só sendo revelada no decorrer da psicoterapia. A partir dos atendimentos realizados, foram levantadas várias categorias referentes à história de vida 
do sujeito em questão; contudo, devido à grande quantidade de informações, realizouse uma seleção para análise e discussão, de onde se tirou: a vivência no presídio, o abuso sexual sofrido, o abuso sexual cometido e a importância do processo psicoterapêutico.

No que diz respeito à vivência dentro da instituição, Henrique relata que não a vê como algo totalmente maléfico. Assim, parece ser capaz de perceber a importância do encarceramento e demonstra agir no sentido, ou seja, vê-lo como algo necessário, como destacado por Jacobson (1975, citado por Balier, 1997). Henrique declara concordar com o Estado quando este interrompe seus crimes, e, assim, agir no sentido de procurar a "saúde" em meio ao ambiente no qual se encontra:

Henrique: "Eu não considero meu tempo perdido não, fiz curso, tive a minha filha, conheci a mãe dela aqui dentro (...). Então eu sou muito grato a Deus, porque, de repente, se eu tivesse lá na rua, talvez já tinha até morrido, ou então arrumado um monte de cadeia, pra quando vir, não sair mais nunca, então, não tá perdido, não".

Ainda em relação à vivência no presídio, podese perceber o que Tavares e Menandro (2004) pontuam sobre a exclusão do sistema, por meio da fala do sujeito sobre a direção do presídio e da maneira como são tratados os "reeducandos":

Henrique: "(...) Eles não gastam o dinheiro que eles ganham com preso não, porque o preso aqui é mantido pela família dele; se ele quiser ir em algum lugar, tem que pagar gasolina, se ele quiser ir no hospital, ele tem que fazer umas manobra; pra pôr o processo dele pra andar, tem que fazer correria, tem que ser particular. Então, na real, eles tão ganhando pra manter o preso aqui dentro, quanto mais segurar ele aqui, melhor (...) Aqueles advogado ali, quando me chama eu não vou, (...).

Essas são apenas algumas das falhas do sistema, mas há também um processo de exclusão entre os próprios presos, uma vez que as pessoas enquadradas no mesmo artigo de Henrique são mal vistas pelos outros presos. Henrique relata casos de violência física e sexual com pessoas presas em seu artigos 213(estupro) e 214( atentado violento ao pudor) do Código penal Brasileiro, o que nos mostra que, também no presídio, impera a Lei de Talião: olho por olho e dente por dente.

Em relação à categoria abuso sofrido, procurou-se trabalhar a forma como a violência foi internalizada. A primeira vez que Henrique fala sobre o abuso é durante a sétima sessão, e é também a primeira vez que fala sobre o abuso com outra pessoa. Essa é uma sessão muito difícil para Henrique, que se emociona várias vezes e expressa sentimentos de vergonha. É somente no decorrer dos outros atendimentos que consegue descrever cenas do abuso. Percebe-se que falar sobre isso é extremamente doloroso para Henrique, e que, a cada sessão, fala o que pode e o que consegue falar.

Durante a décima quinta sessão, Henrique fala sobre a época em que se mudou para a casa de João (a pessoa que o violentou sexualmente); este ia todas as noites ao seu quarto e sempre the perguntava algo sobre sua mãe. Em um desses dias, Henrique conta a João que pressentiu que a mãe fosse morrer, mas não disse isso a ela. Na primeira noite do abuso sexual, pode-se perceber, por meio do relato de Henrique, além da violência sexual, também um pouco da violência física e psicológica pela qual passou:

Henrique: “(...) e ele começou a me apertar na cama 'Porque você não falou pra ela que ela ia morrer? Você sabia', e eu comecei a chorar, e ele falou: 'Não chora, não'. Me enforcou, pegou e começou a tirar minha roupa e falou: 'Hoje, você vai acabar esse medo, seu rapaz'. Nossa, foi três dia de tensão, três noites que (...) (suspira), muito difícil (...). Me bateu na cama, no chão, me levou pro quarto dele, e ele falava assim pra mim 'Porque você não grita?' Eu tinha vontade de gritar, mas minha 
garganta tava inchada. Ele me deu um murro na cabeça, eu tava machucado, eu passei o dia lá dentro do banheiro trancado, ele levou comida pra mim. E, de noite, ele queria de novo, a noite inteira ele me sacaneou.(...) foi muito estranho. Eu tinha medo de morrer lá, e ele falava o tempo inteiro 'Eu vou te matar, você não vai escapar. Você não tem coragem de gritar, você vai ser sempre um inútil, um fraco. Você vai ser mais fraco que os outros, você nunca vai ser nada, você nunca vai ser ninguém'. Quando alguém fala alguma coisa sobre fraqueza perto de mim, chega dá um arrepio, até hoje eu escuto isso direto, ele me falar: 'Você vai ser fraco, você nunca vai ser ninguém' ".

Provavelmente, a criança terá seu desenvolvimento comprometido quando for vista como uma propriedade com a qual o adulto tenta atingir algum objetivo (Miller, 1997), isso porque a criança se percebe e se descobre por meio de sua relação com o outro; é o adulto quem primeiro lhe dará as informações que precisa a respeito dela mesma. Dessa forma, as crianças acreditam no que o adulto diz sobre elas e crescem internalizando todas as informações que os mesmos passam a seu respeito, o que pode ser prejudicial caso, posteriormente, não tenham a oportunidade de discriminar e ressignificar essas informações. Assim, pôdese perceber que as experiências de violência física, sexual e psicológica pelas quais Henrique passou influenciaram negativamente seu comportamento na adolescência e idade adulta.

Após ter sido abusado sexualmente durante três dias, Henrique consegue fugir da fazenda e passa a morar com outras pessoas. Conta que, nessa época, começou a sentir muita revolta e raiva, mas não contou a ninguém sobre o abuso sofrido, procurando se "fechar cada vez mais" (sic). Após algum tempo, relata que tinha vontade de fazer algo de ruim com alguém, o que primeiro aconteceu quando ele tinha quatorze anos, ao matar uma pessoa com vários tiros. Henrique conta que, no momento em que atirava, pensava que assim resolveria seus problemas. Ele parece, então, repetir, com o outro, a violência sofrida, visto que, no decorrer de sua vida, não teve a oportunidade de ressignificá-la. Sanderson (2005) fala sobre a interiorização e exteriorização do abuso sexual sofrido. Inicialmente, Henrique parece interiorizar o abuso (quando procura se fechar), depois ocorre uma exteriorização brusca (mostrandose agressivo, em vez de se mostrar como vítima) e, dessa forma, consegue evitar o contato com os outros. Entretanto, em nenhum desses dois processos o abuso sexual sofrido é trabalhado.

Em relação à categoria abuso cometido, trabalhou-se com o objetivo de compreender a repetição da violência, sendo também abordada a visão que o sujeito possuía dos crimes que cometeu.

Assim, durante a sétima sessão, Henrique conta que queria descontar o que havia acontecido com ele, como uma forma de exteriorizar a raiva já internalizada durante cinco anos.

Henrique: "Eu pensava, tipo assim, quando a gente apanha, se a gente bater, tá resolvido (...). Eu pensava que, se eu fizesse alguma coisa de mal com os outros, que tipo fosse aliviar, e não foi isso que aconteceu, ficou pior".

Para Henrique, o abuso sexual sofrido foi, acima de tudo, muito humilhante, baseado em uma relação de poder, o que, segundo Sanderson (2005), teria fortes implicações na maneira como ele praticaria o abuso.

Em sua fala, fica nítida a sensação de poder que João possuía sobre ele, e, assim, pôde-se observar que era essa a sensação que Henrique buscava ao abusar dos meninos. Miller (1997) ressalta que esse ciclo é típico de pessoas que foram manipuladas e lesadas na infância, que transferiram seu ódio a inocentes e tendem a repetir os mesmos padrões, pois vivem situações não resolvidas. Henrique expressa 
esse desejo de se sentir forte e poder manipular o medo no outro, pois agora ele estava invertendo uma situação anterior e, ao mesmo tempo, encobrindo seus verdadeiros sentimentos de impotência:

Henrique: "(...) eu tinha vontade de fazer alguma coisa com criança, aí fui juntando as coisas que aconteceu e aí eu peguei e falei 'Ah, eu vou pegar um muleque e vou fazer alguma coisa com ele, menos matar, eu não morri'. Mas eu queria fazer a pessoa se sentir bem rebaixada, humilhar uma pessoa até não ter mais jeito, fazer a pessoa ficar oprimida, entendeu? Sentir assim o dono da situação, ver a pessoa pedir pelo amor de Deus e tal, e oprimir alguém assim, que tivesse mais ou menos aquela idade que eu tinha um tempo atrás".

Nesse momento, pôde-se confirmar o que Rada (1978, citado por Cohen \& Figaro, 1996) disse sobre esse tipo de crime, que envolve também poder, controle e humilhação, e, não possui, necessariamente, fins de satisfação sexual.

Ao falar sobre seus crimes, Henrique traz também a noção de responsabilidade, colocada pela psicoterapia fenomenológica (Augras, 1986/2002), entendendo-se como o único responsável pelos atos cometidos. Assim, não mostra uma tentativa de acusar os adolescentes, ou dizer que estes consentiram, fato que é muito comum, segundo Koshima (2003). Henrique conta que prometia dinheiro para os garotos e assim conseguia levá-los para um lugar deserto, tanto na primeira vez quanto nas outras. O sujeito não usa o fato de os garotos já terem sido abusados por ele uma vez para acusá-los de consentirem com o abuso quando os chamava pela segunda vez.

No que diz respeito ao processo terapêutico, este foi essencial para a ressignificação de alguns conceitos do sujeito; para isso, foi preciso voltar ao passado várias vezes e reviver alguns sentimentos.
Na sétima sessão, Henrique afirma que já tentou esquecer o abuso que sofreu, mas não consegue. Essa postura mostra o que Miller (1997) diz sobre não olhar para a história passada, por esta, muitas vezes, ser dolorosa. Contudo, dessa forma, o paciente é repetidamente determinado por essa história, pois vivencia situações não-resolvidas. Apesar desta postura defensiva, existe, em Henrique, uma intenção de falar. Embora se mostre confuso sobre isso, é capaz de reconhecer a importância de expressar esses sentimentos dolorosos. Quando é questionado sobre como se sente ao falar do passado, Henrique diz:

Henrique: "Tem hora que eu penso assim 'Porque ficar mexendo nesse trem? Já passou tanto tempo'(...). Mas depois vem o outro lado, uma cobrança assim ou uma resposta, não sei, né, que parece que é um lixinho que tá lá num cantinho e a gente pega ele e, aos pouquinhos, vai jogando fora. Não sei, parece que dá uma aliviada, entendeu? Sei lá, é diferente. É uma coisa que nunca aconteceu".

Olhar para o passado permitiu também trabalhar os sentimentos de culpa de Henrique. Aqui será analisada a culpa por ter sido vítima de abuso sexual e a culpa por não ter dito à mãe que esta iria morrer.

No que concerne à culpa em relação ao abuso que sofreu, esta começou a ser trabalhada com Henrique durante a sétima sessão. Henrique expressa uma culpa por ter ido morar na casa de João e por não ter fugido de lá antes de o mesmo iniciar o abuso sexual. Por meio do processo psicoterapêutico, buscou-se desenvolver, com o paciente, um questionamento reflexivo, para que este percebesse e escutasse o que ele mesmo estava dizendo (visto que, em sua fala, reconhecia que, com dez anos, não dava para prever o que aconteceria), dando início a uma reflexão sobre essa culpa .

O sentimento de culpa foi um dos temas trabalhados em diversas sessões, com o objetivo de mostrar a Henrique que ele não era culpado
"Eu pensava, tipo assim, quando a gente apanha, se a gente bater, tá resolvido (...). Eu pensava que, se eu fizesse alguma coisa de mal com os outros, que tipo fosse aliviar, e não foi isso que aconteceu, ficou pior".

Henrique 
pelo abuso sofrido, uma vez que dizia sentirse responsável pelo mesmo. Essa culpa por ter sido vítima fazia-o ficar continuamente preso ao passado, àquilo que não fez, àquilo que não falou, àquilo que não pensou. Outro ponto da culpa fazia-o ficar preso ao futuro; conta que se culparia caso acontecesse algo de ruim com a filha ou com algum parente, pois sentiria que era uma cobrança pelos crimes que ele cometeu. De acordo com Petrelli (1999), é objetivo da terapia reinserir o paciente no fluxo atual do tempo, no qual se faz a história como protagonista, ou seja, inserí-lo no tempo presente.

Já em relação ao abuso cometido, Henrique revela, em sua fala, muita culpa pelos crimes que cometeu. Assim, teme que os garotos possam envolver-se em algo parecido com o que fez; relata que sonha com os mesmos, procurando pedir-lhes perdão pela violência que cometeu. Contudo, Henrique é o único responsável pela violência cometida contra os garotos, e, em nenhum momento do processo psicoterapêutico, essa responsabilidade lhe foi retirada.

Em outro momento, foi trabalhada também a culpa que Henrique sentia por não ter dito à mãe que a mesma iria morrer. Em sua própria fala, diz que não conseguia conversar sobre o assunto com a mãe, mas não percebe isso de forma consciente. Assim, buscou-se ampliar a visão que Henrique tinha sobre a morte da mãe, incluindo percepções de que ele era pequeno, de que não iriam acreditar, caso ele contasse, de que a mãe não o deixava falar, etc., percepções essas que justificavam o que havia acontecido.

Ainda em relação ao processo psicoterápico, trabalhou-se também no sentido de desmitificar a imagem de João. Isso foi feito por meio de atividades (ex. escrever uma carta para João sobre seus sentimentos em relação ao mesmo ou ainda algo que gostaria de ter dito a ele e não pôde) e atendimentos terapêuticos focados na experimentação de sentimentos, na tentativa de se refletir sobre alguns conceitos e reformulá-los.
Miller (1997) salienta que a capacidade de reviver e experienciar sentimentos dolorosos possibilita transferir o ódio a quem o merece. Henrique afirma que, após o abuso que sofreu, sentia muita raiva e ódio, e, assim, procurou "descontar" em quem não tinha nada a ver com o fato. A prova de que Henrique não experienciou os sentimentos em relação a João está no fato de que procura negá-los, dizendo (oitava e décima quarta sessões) que nunca pensou em matá-lo ou vê-lo morrer queimado. A fala de Henrique mostra que existem sentimentos que ele não se permite expressar, por isso, em outros momentos, procurou-se trabalhar mais sobre o ocorrido. Na décima quarta sessão, ao ser questionado novamente sobre os sentimentos em relação a João, Henrique diz que este era muito bobo, mas que ele não tem mágoa do mesmo. Durante essa sessão, foi colocada a possibilidade de expressão dos sentimentos de raiva, ódio e mágoa, pois estes são sentimentos compreensíveis frente à situação pela qual passou. Isso é reiterado na sessão seguinte, quando Henrique revela que realmente sente mágoa e raiva de João.

O objetivo da intervenção terapêutica era fazêlo ressignificar o abuso sexual sofrido e criar condições para que pudesse falar sobre este, bem como expressar sentimentos ainda não manifestos.

A imagem da pessoa que o violentou ainda era muito recorrente para o sujeito. Exemplos disso são os constantes sonhos com João, nos quais este o ameaçava e corria atrás dele para matálo. Nestes, Henrique vê João como muito forte e mau, e se vê como pequeno e fraco. Isso indica que o sujeito pareceu absorver o que João disse a seu respeito; como já ressaltado, trata-se de um processo de construção do mundo da criança.

Nos sonhos que tem com João, este lhe diz que nunca o deixará em paz, que ele é muito medroso e Henrique diz que realmente se sente medroso. Assim, é questionado do que especificamente ele tem medo, e ele fala do 
medo de que aconteça algo com sua filha. Henrique recebe a confirmação de seu medo, o que Hycner (1997) chamaria de diálogo com o problema. É dito ao sujeito que o medo é algo natural do ser humano, e ele tem razões em ter medo, pois está longe da filha e não sabe, ao certo, o que se está passando com a mesma. Henrique é ainda estimulado a ver João como uma pessoa que também tem medo, assim como ele tem; dessa forma, procura-se diminuir o poder que João possuía sobre o sujeito.

Trabalhou-se, com o sujeito, conceitos como maldade e covardia. Foi visto que, ao falar de si mesmo, Henrique percebe seus crimes como um ato de covardia, contudo, ao falar sobre João, Henrique o vê como ignorante e extremamente mau. Ao ver a pessoa que o violentou como mau, Henrique atribuía a ele uma força muito grande, e, assim, sentia medo dele. É natural que a criança sexualmente abusada não consiga enxergar os abusadores como covardes, mitificando a figura dos mesmos, contudo, o adulto, que fora sexualmente abusado na infância, deve refletir sobre as experiências e mensagens que recebeu quando criança, e, assim, discernir as representações construídas durante o processo de vitimização. Hoje, Henrique pode ver que, para um adulto ser forte perante uma criança ou com uma arma na mão, é fácil, pois trata-se de uma 'luta' injusta e desigual, o que, por sua vez, não é sinal de força, e sim, de covardia. Dessa forma, não precisa mais sentir-se fraco e covarde, e ver João como forte. Hoje pode concebê-lo também como covarde e, assim, diminuir o medo que tem dele. Isso vem ao encontro do que Miller (1997) explicita: o forte é aquele que sabe de sua impotência porque a vivenciou, portanto, não tem necessidade de manipular e mostrar sua força por meio do desprezo.

Essa imagem de João também pôde ser desmitificada por meio da carta que Henrique escreveu para o mesmo. Aquela fora sugerida pela psicoterapeuta, com o objetivo de facilitar a exteriorização de sentimentos em relação a
João. Na décima oitava sessão, Henrique levou a carta, na qual tratou das manipulações que sofreu. Escreveu que João havia dito que ele nunca saberia o que é amar, e que ninguém iria gostar dele; responde falando sobre a filha e mostrando o quanto a ama e a maneira como ela o trata. Escreveu que João falava que ele nunca conseguiria contar a ninguém sobre o abuso sofrido e ressalta que isso também era mentira. Ainda nessa sessão, é capaz de perceber outras mentiras de João:

Henrique: "Ele falou que eu ia ser igual a ele. Falou que eu ia ser um monstro, um psicopata (...); por muito tempo eu acreditei; pensava que isto era verdade. Mas eu vi que eu não era desse jeito (...), por um bom tempo tentei agir assim, mas não tem nada a ver com a minha pessoa. Eu não sou assim".

Nessa sessão, Henrique mostra-se capaz de perceber como tentou reproduzir o comportamento de João, contudo, conta também que fora capaz de rever o que ocorreu e decidir agir diferente.

Durante a vigésima sessão, Henrique relata que, há uma semana, não sonha com João e que, pela primeira vez, acordou de madrugada e foi capaz de voltar a dormir, fato que antes era impossível, pois relatara, em sessões anteriores, ter muito medo do escuro, tanto que, em sua cela, havia três lâmpadas, e que, quando perdia o sono, não conseguia dormir mais.

Dessa forma, Henrique é capaz de começar a perceber e desvincular-se do que o 'outro' disse sobre ele e construir sua própria percepção acerca de si mesmo. Essa é a noção implícita de responsabilidade na psicoterapia fenomenológica, sendo que o sujeito não é responsável por ter sido vítima no passado, mas é responsável por continuar a ter uma postura de vítima passiva.

Trabalhou-se, portanto, com o objetivo de trazêlo ao tempo presente, que é o único no qual
"Ele falou que eu ia ser igual a ele. Falou que eu ia ser um monstro, um psicopata (...); por muito tempo eu acreditei; pensava que isto era verdade. Mas eu vi que eu não era desse jeito (...), por um bom tempo tentei agir assim, mas não tem nada a ver com a minha pessoa. Eu não sou assim".

Henrique 
se pode produzir, pois, como lembra Sartre (n/ d), "Agora não importa o que fizeram de mim, mas o que eu faço com o que fizeram de mim".

\section{Considerações finais}

A proposta inicial do trabalho foi mostrar a realidade existencial do sujeito em questão; para isso, foi necessário vê-lo além do estigma de abusador sexual. A psicoterapia com base fenomenológica defende a idéia de que o rótulo não ajuda em nada, somente nos afasta da pessoa e cria a idéia falsa e simplista de encará-la como boa ou má.

A repetição da violência sexual apresentou-se como algo presente na história do sujeito em questão; contudo, vale lembrar que nem todas as pessoas que cometeram abusos foram abusadas na infância, e nem todos os abusados irão abusar. Ressalta-se também a importância de se tratar a criança abusada para oferecerIhe a oportunidade de ressignificar a violência sofrida e romper o ciclo de repetição. Se cabe ao Estado olhar para as vitimas, como se pode perceber, esse nem sempre cumpre seu papel. Contudo, olhar para as crianças e até mesmo para o ser humano não é um papel apenas do Estado, mas de pais, professores, amigos, profissionais e nosso, enquanto psicólogos e cidadãos.

Fica evidente também a importância de se atender, em psicoterapia, o autor de violência sexual, visto que a prisão não é um tratamento, não corrige, nem ao menos "reeduca", como ela mesma propaga. Ao se 'jogar' a pessoa na prisão, apenas se repete com ela a situação de exclusão que a mesma conhecia tão bem (Tavares e Menandro, 2004). Entretanto, o presídio funciona como uma imposição da lei e das normas sociais. Nesse sentido, prisão e psicoterapia podem ser vistas não como processos excludentes, mas sim, complementares.

É também extremamente necessária e urgente a realização de um trabalho multidisciplinar com assistentes sociais, agentes carcerários, advogados, psicólogos, etc. O papel do psicólogo, nesse ambiente, não pode, de forma alguma, restringir-se à elaboração de laudos e à conseqüente rotulação do sujeito. Aliás, a rotulação é um trabalho totalmente antipsicológico, visto que estigmatiza e faz com que a prioridade seja a instituição, e não a pessoa atendida.

O objetivo de se fazer uma retrospectiva histórica da violência sofrida não foi justificar o comportamento abusivo do sujeito em questão, e sim, compreender como ele se desenvolveu nessa pessoa em particular. Olhar para o passado é um trabalho doloroso, contudo, este é necessário, pois, muitas vezes, sem perceber, repete-se o passado na tentativa de se corrigilo. Assim, trata-se de um passado que não passou, como colocado por Henrique: "parece que aconteceu ontem, aconteceu hoje e vai acontecer amanhã".

Acredita-se que esse seja apenas o começo de um longo processo que Henrique irá percorrer, visto que as "imposições" que nos são colocadas desde a infância não são facilmente desvinculadas. Fica a proposta da psicoterapia de contribuir para que o sujeito possa olhar sua própria história e agir de forma efetiva e consciente sobre esta.

Não existe a certeza de que Henrique, pelo fato de ter analisado e compreendido alguns pontos de sua história, não vá reincidir no crime. Entretanto, foram oferecidas ao sujeito, por meio do processo psicoterápico, oportunidades de ressignificar sua própria história, com base na idéia de que, a partir do momento em que a pessoa amplia a consciência a respeito de si mesma, pode também ser capaz de ver e reconhecer o outro como possuidor de direitos, e não como objeto.

Procurou-se compreender não o 'porquê', mas o 'como' uma pessoa se torna um criminoso, visto que o 'como' nos remete à 'relação', ao que ocorre 'entre' as pessoas e não somente 'com' as pessoas. 
A frase de Gandhi "Olho por olho... e o mundo acabará cego" mostra a importância de se romper o círculo vicioso da violência, e isso não será possível se continuarmos a olhar só para a vítima. Se, como psicólogos, acreditamos que as pessoas se constroem por meio de suas relações com os outros, devemos dirigir nossos olhares também para o autor de violência, para compreendê-lo em sua totalidade. Fechar os olhos para os mesmos é fechar os olhos para a violência, e essa é a pior forma de alimentá-la. Nesse sentido, é papel da Psicologia olhar o humano e contribuir para que o social também seja capaz de reconhecê-lo.
Psicóloga, especializanda em Gestalt-terapia pelo Instituto de Angélica de Jesus Gestalt-terapia de Goiânia - ITGT Atua como Psicóloga no Programa Repropondo: Atendimento a Autores de Violência Sexual, do Projeto: "Ações de Enfrentamento da Violência Sexual Infanto-Juvenil na Região Metropolitana de Goiânia", vinculado ao CEPAJ/UCG

Av. Bela Vista, Km 2 s/no , Jardim Olímpico, Goiânia, Goiás CEP 74.860-210 Tel.:3227-1717/9671-8996 E-mails:nubiaaj@gmail.com,nubiaaj@hotmail.com
AUGRAS, M. O Ser da Compreensão: Fenomenologia da Situação de Psicodiagnóstico. Petrópolis: Vozes, 1986-2002.

AZEVEDO, M. A.; GUerRA, V. N. A. Pele de Asno não É só História... Um Estudo sobre a Vitimização Sexual de Crianças e Adolescentes em Família. São Paulo: Roca, 1988.

Crianças Vitimizadas: A Síndrome do Pequeno Poder. Violência Física e Sexual contra Crianças e Adolescentes. São Paulo: Iglu, 1989.

A Violência Doméstica na Infância e Adolescência. São Paulo: Robe, 1995.

BALIER, C. Psicopatologia dos Autores de Delitos Sexuais contra Crianças. In: Gabel, M. (org.). Crianças Vítimas de Abuso Sexual. São Paulo: Summus, 1997, pp. 114-119.

BASS, E.; THORTON, L. (orgs.). Nunca Contei a Ninguém. São Paulo: Harper \& Row do Brasil, 1985.

COHEN, C.; FIGARO, C. J. Crimes Relativos ao Abuso Sexual. In: Cohen, C.; Segre, M.; Ferraz, F. C. (orgs.). Saúde Mental, Crime e Justiça. São Paulo: Edusp, 1996, pp. 149-169.

ESBER, K. M. Pessoas que Cometeram Violência Sexual: Patologia Individual ou Questão Familiar? Monografia de Pósgraduação em Terapia de Famílias e Casais. Universidade Católica de Goiás, Goiânia, 2005.

FURNISS, T. Abuso Sexual da Criança: uma Abordagem Multidisciplinar. Porto Alegre: Artes Médicas, 1993.
GABEL, M. (org.). Crianças Vítimas de Abuso Sexual. São Paulo: Summus, 1997.

HYCNER, R. De Pessoa a Pessoa: Psicoterapia Dialógica. São Paulo: Summus, 1995

KOSHIMA, K. Palavra de Criança. In: Gadelha, G.; Barbosa, H. (orgs.). Construindo uma História: Tecnologia Social de Enfrentamento à Violência Sexual contra Crianças e Adolescentes. Salvador: CEDECA-BA, 2003, pp. 133-144.

MILLER, A. O Drama da Criança bem Dotada. São Paulo: Summus, 1997.

PETRELLI, R. Para uma Psicoterapia em Perspectiva Fenomênico-Existencial. Goiânia: Editora UCG, 1999.

SANDERSON, C. Abuso Sexual em Crianças. São Paulo: M. Books, 2005 .

SOUSA, S. M. G.; MORAIS NETO, O. L. (orgs.). Abuso e Exploração Sexual de Crianças e Adolescentes na Região Metropolitana de Goiânia (1992-1996). Goiânia: Cerne, 1997.

TAVARES, G. M.; MENANDRO, P. R. M. Atestado de Exclusão com Firma Reconhecida: o Sofrimento do Presidiário Brasileiro. Psicologia: Ciência e Profissão, Brasília, v. 24, n. 2, pp. 86-99, 2004. 